\title{
ICE SURGES ON THE MULDROW GLACIER, ALASKA
}

\author{
By A. E. Harrison \\ (Department of Electrical Engineering, University of Washington, Seattle, Washington, \\ U.S.A.)
}

Spectacular advances by Alaskan glaciers are not a rare occurrence. At least four ice surges have been reported during the last 30 years in the Alaskan Range (Post, I96o). It is probable that other surges have occurred without being recognized. The earliest and classic example was the Black Rapids Glacier advance in 1936-37 (Moffit, I942). The Muldrow Glacier surge in I 956 and 1957 furnished considerable information about these surges, because aerial photography of the area was available before, during and after the surge. In addition, the region is visited frequently by climbing expeditions. As a result, new information on wave velocities, mass velocities and the mechanism of flow during surges is available.

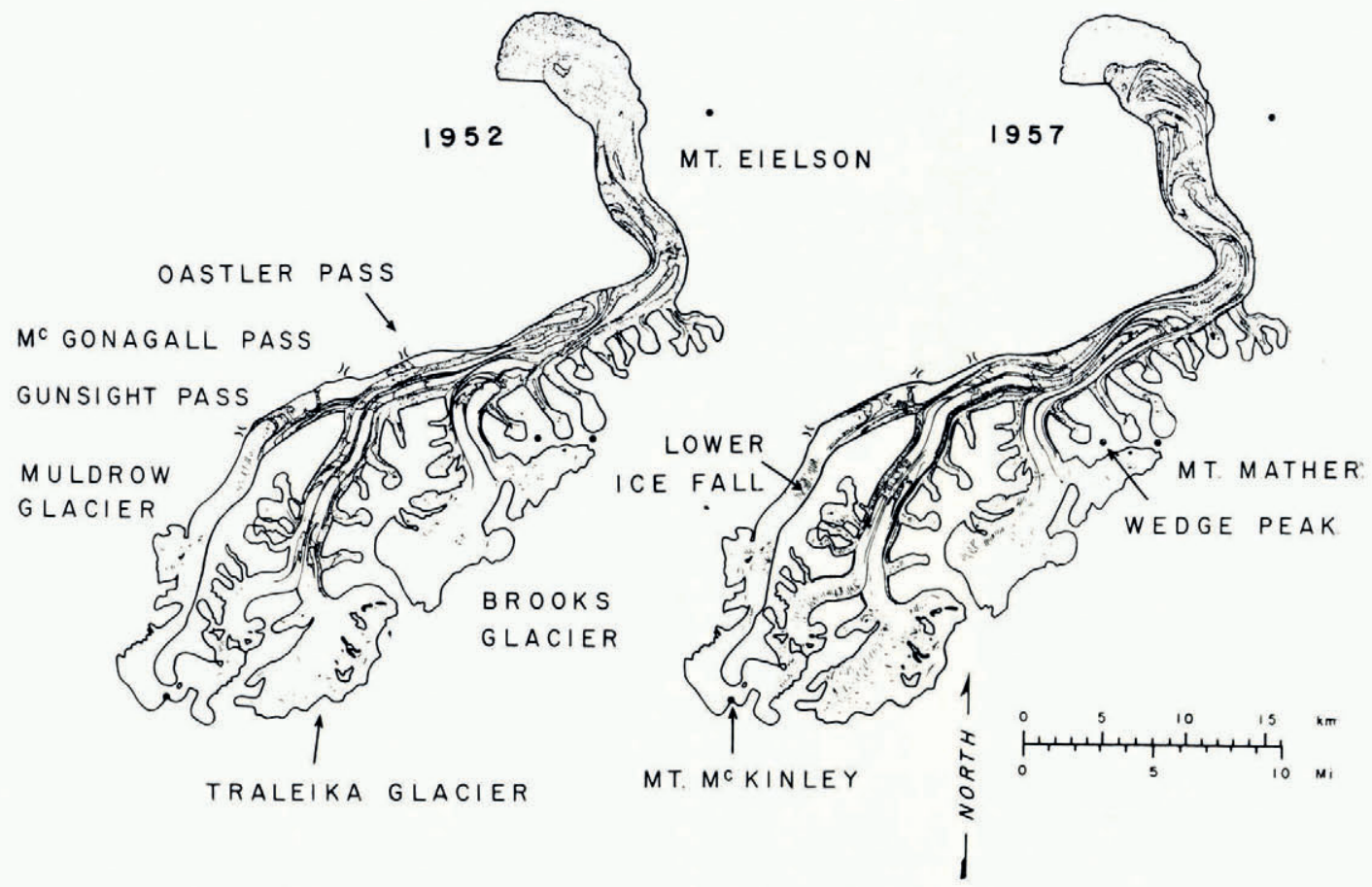

Fig. I. Maps of the Muldrow Glacier system, showing landmarks and the location of surface debris patterns in 1952 and 1957 , i.e. before and after the surge

The geographical arrangement of the Muldrow Glacier system and some of the named landmarks are shown in Figure I. Figure 2 is an aerial view of the region in 1959. Mills's Big Crevasse (Mills, I96r) was located on Traleika Glacier $6 \cdot 4 \mathrm{~km}$. from its junction with Muldrow Glacier near McGonagall Pass and is used as the reference point for distances along the glacier. It is the author's belief that the Muldrow Glacier surge started at this point a few days before the arrival of the Mills party on 25 May 1956.

As a surge moves down a glacier, there is a region where the ice velocity is at a maximum. The ice is in compression below this region, it is becoming thicker, crevassing is minor and it occurs principally along the lateral margins. Above this region the ice is in tension, huge 365 


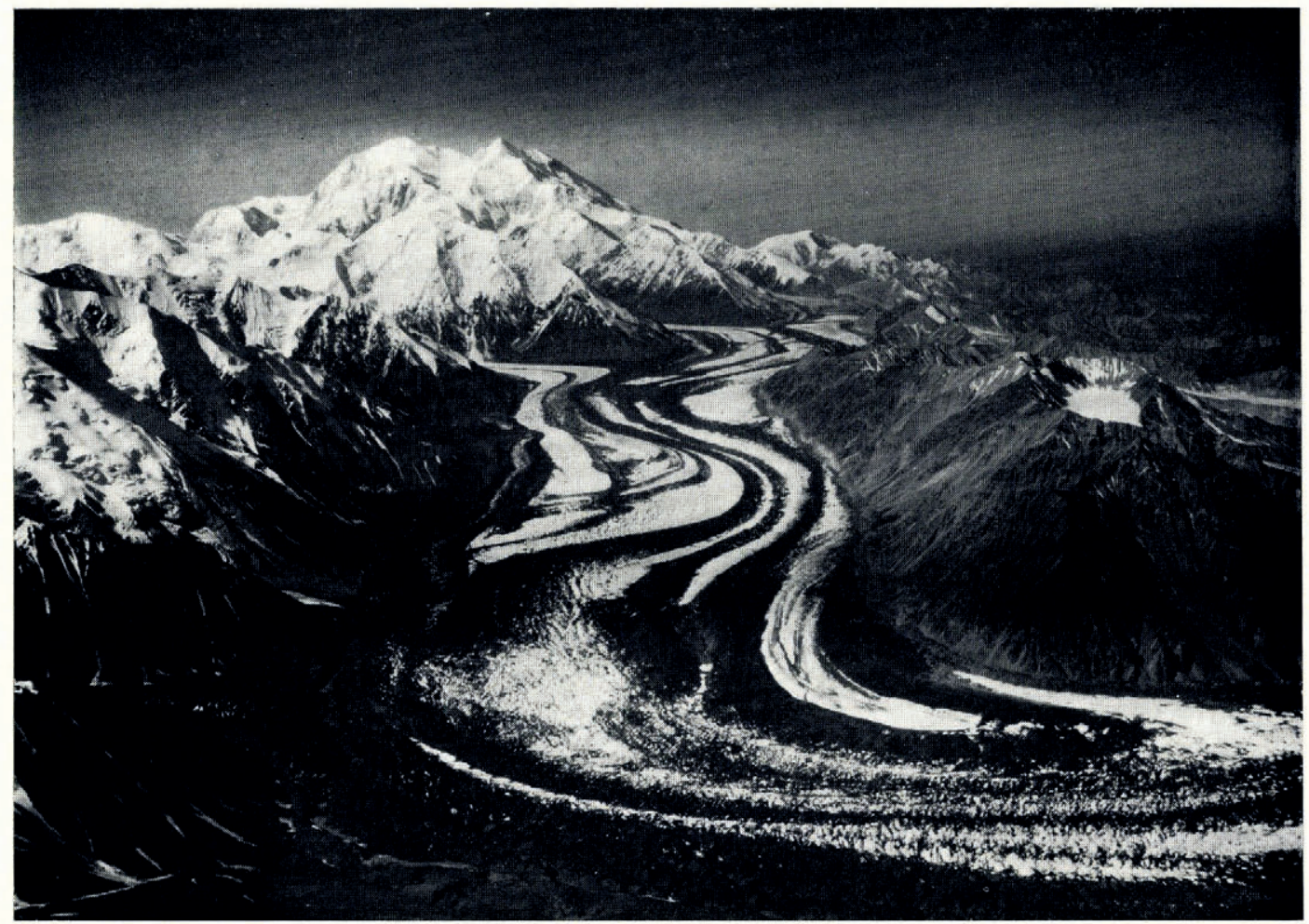

Fig. 2. Mount McKinley, Alaska, and the Muldrow Glacier in 1959. The curved morainal patterns indicate that surges have occurred repeatedly on this glacier. (Photograph by Bradford Washburn)

crevasses stretch across the glacier, the ice thickness decreases and the surface drops. The boundary between ice in compression and ice in tension represents a distinct phase change which can be recognized readily. Movement of this phase boundary can be measured and it provides one measure of the velocity of the wave traveling down the glacier during a surge.

A second phase change, which can be identified and used as a measure of a somewhat different wave velocity, is the velocity jump where the rapidly moving surge meets the slowmoving or stationary ice. The position of this phase change can only be estimated in the early stages of the Muldrow Glacier surge, but its recognition became quite obvious when a steep wall of ice moved into the stagnant tongue during the last stages of its advance (personal communication from Warren F. Steenbergh). This velocity jump occurs in both surge flow and normal waves on glaciers.

Another phase change has also been identified for the Muldrow Glacier surge, although its location must be estimated rather crudely. It is included because it lends confirmation to some of the other values for the wave velocity. This change is defined by the location along the glacier where the ice level has dropped an estimated i $5 \mathrm{~m}$. (personal communications from James Mills and Leslie A. Viereck).

Wave velocities through the ice are greater than the movement of the ice itself. The mass velocities for the ice were estimated from the changed positions of debris patterns on the surface. These positions were known from photographs taken on 13 August 1956 (personal communication from Leslie A. Viereck). The earlier positions were based on the $195^{2}$ map (Fig. I) and times of arrival of the velocity jump were estimated. These dates are less depend- 
able, but the mass velocities estimated in this manner are reasonable and certainly indicate an order of magnitude.

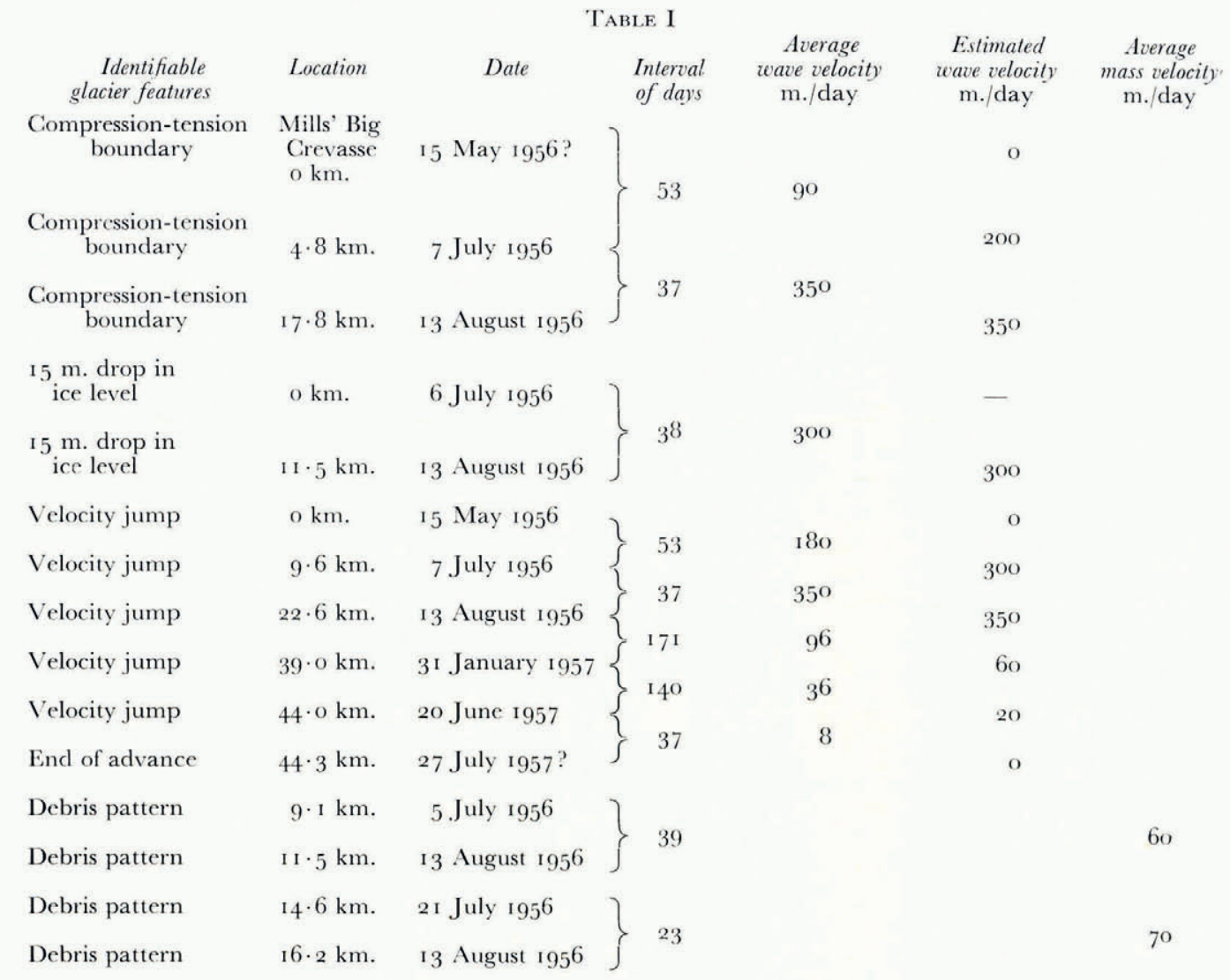

The location of these features on different dates are given in Table I and indicate a consistent sequence of velocities during the Muldrow Glacier surge. The wave and mass velocities are comparable to those observed on Medvezhy Glacier, Pamir Range, in I963 (personal communication from G. A. Avsyuk, I963). The wave velocities are also similar to those reported by Moffit (I942) and Desio (I954).

Prior to the surge in 1956, the fork of Muldrow Glacier above its junction with Traleika Glacier was responding to an excess of accumulation during the preceding decade. The annual ice movement was $43 \mathrm{~m}$./yr. and a wave of thickening ice was moving down the glacier with a velocity of $250 \mathrm{~m}$./yr. The ratio between wave and mass velocities for surges is remarkably similar to the ratio of these velocities during normal glacier flow, although both the wave and the ice mass move as far in a day during a surge as they would normally move in a year.

Viereck's (personal communication) photographs on I3 August I956 show that the Muldrow Glacier fork and Brooks Glacier were just beginning to move at that time, although the compression-tension boundary was several kilometers beyond the Brooks Glacier junction. The ice level had begun to fall at Oastler Pass but not at the Brooks Glacier junction. Subsequent behavior of tributaries which were truncated but not drained when the ice level dropped (Post, I960) and the evidence of simultaneous and rapid flow by the drained tribu- 
taries imply that these glaciers are drained by the tensile forces associated with the main surge. The drainage migrates upward until the ice thickness is no longer sufficient to maintain the tension, and the rapid movement stops suddenly at that point.

Morainal patterns on Muldrow Glacier (Figs. I and 2) indicate that at least four surges have occurred on this glacier in the last 200 years. Inspection of the $195^{2}$ aerial photographs suggests that the prior surge also originated on Traleika Glacier and drained the Muldrow Glacier fork. The prior surge occurred before I9i2 (Browne, I9i3) but after igo6 (Sheldon, 1930). Many other glaciers on Mount McKinley and elsewhere in the Alaska Range also show evidence of repeated surging. Medvezhy Glacier in the Pamirs has surged repeatedly with a periodicity of approximately 15 years (personal communication from G. A. Avsyuk, I963). The occurrence of a surge on Ellesmere Island, Canada (Hattersley-Smith, I964), in a region of low annual accumulation adds another facet to the problem posed by this unexplained phenomenon, and points to the need for a concerted effort to detect and measure a surge in its earliest stages and throughout its brief history.

MS. received 22 November 1961 and in revised form ${ }_{15}$ May ${ }_{1964}$

\section{REFERENCES}

Browne, B. 1913. The conquest of Mt. McKinley. New York, G. P. Putnam's Sons.

Desio, A. 1954. An exceptional glacier advance in the Karakoram-Ladakh region. Journal of Glaciology, Vol. 2, No. 16, p. $3^{8} 3^{-8}$.

Hattersley-Smith, G. 1964. Rapid advance of glacier in northern Ellesmere Island. Nature, Vol. 201, No. 4915, p. 176 .

Mills, J. 1961. Airborne to the mountains. New York, A. S. Barnes and Co., Inc.; London, Thomas Yoseloff, Ltd.

Moffit, F. H. 1942. Geology of the Gerstle River district, Alaska. U.S. Geological Survey. Bulletin 926 B, p. $146-57$.

Post, A. S. 1960. The exceptional advances of the Muldrow, Black Rapids and Susitna Glaciers. Fournal of Geophysical Research, Vol. 65, No. 11, p. 3703-12.

Sheldon, C. 1930. The wilderness of Denali: explorations of a hunter-naturalist in northern Alaska. New York, Charles Scribner's Sons. 